\title{
First record of Seticornuta Morley (Hymenoptera, Ichneumonidae, Metopiinae) from Brazil and description of a new species
}

\author{
Araujo, CR. ${ }^{a, b, c *}$ and Penteado-Dias, AM..$^{a, b *}$ \\ aprograma de Pós-Graduação em Ecologia e Recursos Naturais - PPGERN, Universidade Federal de São Carlos - \\ UFSCar, Rod. Washington Luiz, Km 235, CP 676, CEP 13565-905, São Carlos, SP, Brazil

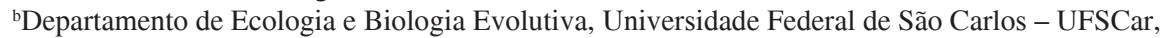 \\ Rod. Washington Luiz, Km 235, CP 676, CEP 13565-905, São Carlos, SP, Brazil \\ ' Laboratório de Ecologia de Artrópodes e Pequenos Vertebrados, Embrapa Meio-Norte, UEP Parnaíba, \\ BR 343, Km 35, CP 341, CEP 64200-970, Parnaíba, PI, Brazil \\ *e-mail: carolina.r.araujo@gmail.com; angelica@ufscar.br
}

Received May 11, 2011 - Accepted July 4, 2011 - Distributed May 31, 2012

(With 11 figures)

\begin{abstract}
A new species of Seticornuta from Brazil is described and illustrated, the first record of this genus for the Brazilian fauna. This new species was found in a study that aimed to enhance knowledge of the Brazilian fauna of Metopiinae, analysing samples from the hydrographic basin of Rio Mogi Guaçu. A diagnosis, along with distribution information for Seticornuta species are provided.
\end{abstract}

Keywords: Seticornuta jacutinga, neotropical fauna, taxonomy, parasitoid.

\section{Primeiro registro de Seticornuta Morley (Hymenoptera, Ichneumonidae, Metopiinae) do Brasil e descrição de uma nova espécie}

\begin{abstract}
Resumo
Uma nova espécie de Seticornuta é descrita e ilustrada, sendo a primeira citação desse gênero para a fauna brasileira. Essa nova espécie foi encontrada em um estudo que teve como objetivo ampliar o conhecimento da fauna brasileira de Metopiinae, analisando-se amostras de localidades pertencentes à Bacia do Rio Mogi Guaçu. São apresentadas diagnoses e informações sobre a distribuição para as espécies de Seticornuta.
\end{abstract}

Palavras-chave: Seticornuta jacutinga, fauna neotropical, taxonomia, parasitóide.

\section{Introduction}

Ichneumonidae is the largest family of Hymenoptera and one of the largest of Insects, with at least 60,000 species estimated. They occur throughout the world, with more described species in temperate regions. They are mainly of solitary parasitoids of Lepidoptera, Coleoptera and Hymenoptera Symphyta, constituting the dominant part of biodiversity in any terrestrial ecosystem, natural or altered, and are commonly sampled by the usual techniques. Due to this dominance, they exert a strong ecological impact in terrestrial environments (La Salle and Gauld, 1993).

Metopiinae is a medium-sized cosmopolitan subfamily of Ichneumonidae, comprising aproximately 700 described species worldwide, which are classified in 27 genera ( $Y u$ and Horstmann, 1997). It is almost certainly a monophyletic group, defined by having the lower face and clypeus confluent and not separated by an impressed groove, scape short and more or less goblet-shaped, malar space short without subocular groove, and with upper margin of lower face protuberant, forming an interantennal process. Some of the largest species are of aposematic colouration and are probably Batesian mimics of aggressive vespids. Metopiinae are solitary larval/pupal koinobiont endoparasitoids of Lepidoptera, and hosts are either caterpillars that feed exposed on plants or those that feed in weak concealment (Gauld et al., 2002).

Townes, H. and Townes, M. (1966) included eight genera and 24 species of Metopiinae from the Neotropical region. De Santis (1980) recorded only seven Brazilian species distributed in four genera. Based on intensive biological investigation of the Ichneumonidae fauna of Costa Rica, Gauld et al. (2002) found 14 genera and 130 species of Metopiinae. Taxonomic studies with the material from the DCBU collection of the Departamento de Ecologia e Biologia Evolutiva of the Universidade Federal de São Carlos, SP, Brazil, from different localities, have revealed several new species and new occurrences of species in the Brazilian ichneumonid fauna (Loffredo and Penteado-Dias, 2008a, b; Onody et al., 2009a, b). In 
one of these studies, Araujo and Penteado-Dias (2011) described two new Brazilian species of Metopiinae, of the genera Metopius and Trieces, collected in areas of Atlantic Forest and Amazonia, respectively.
Seticornuta Morley, 1913 is a small genus comprising six described species: $S$. apicalis Cresson, 1864 and S. terminalis Ashmead, 1896 in the USA; S. albopilosa Cameron, 1907 in India; S. cortesi Porter, 1998 in Chile
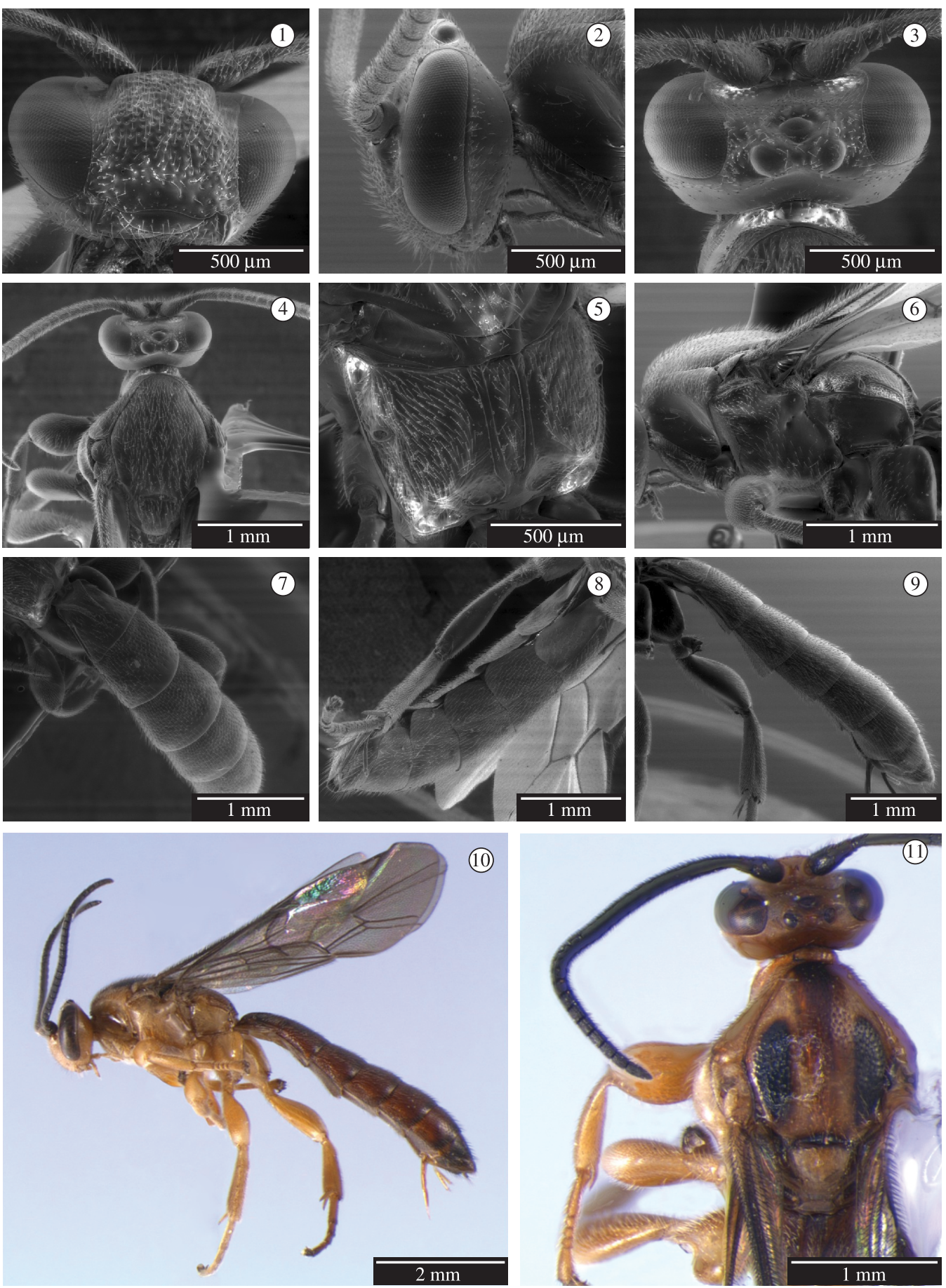

Figures 1-11. Seticornuta jacutinga sp. n.: 1) head (frontal view), showing mandibles and labrum; 2) head (lateral view); 3) frons, showing ocellar triangle; 4) mesoscutum and scutellum; 5) propodeum; 6) mesosoma (lateral view); 7) metasoma (dorsal view); 8) metasoma (ventral view) showing broad laterotergites; 9) metasoma (lateral view) showing ovipositor; 10) habitus, female holotype; 11) colours of frons and mesoscutum. 
and S. altamirae Gauld \& Sithole, 2002 and S. cryptica Gauld \& Sithole, 2002 in Costa Rica (Yu et al., 2005). Thus there are few described species, known from a few, scattered locations. Both U.S.A species have been reared from Pyralidae (S. apicalis reared from Acrobasis and S. terminalis from Nephopterix species), and the hosts of the other species are unknown (Yu et al., 2005).

In some features, Neotropical species of Seticornuta resemble Leurus species, with the small, more or less enclosed rhombic areolet in the fore wing (which can be absent in Leurus) and both have the lateromedian longitudinal carinae of the propodeum fused into a broad ridge behind the posterior transverse carina (Figure 5). Gauld et al. (2002) define Seticornuta and Leurus and propose that these are monophyletic sister lineages. Seticornuta clearly differs from Leurus by the weakly concave margin of clypeus, exposing the labrum (an apomorphy of the genus) and the slender mandible, without a basal lobe (Figure 1).

This work describes a new neotropical species of Seticornuta, the first record of this genus for the Brazilian fauna of Metopiinae.

\section{Material and Methods}

Seticornuta jacutinga sp. n. was found in a study of the Metopiinae fauna in forest and "savanna" (Brazilian cerrado) areas of the hydrographic basin of Rio Mogi Guaçu, covering localities in the States of Minas Gerais (Bom Repouso, Jacutinga, Andradas and Borda da Mata) and São Paulo (Pontal and Luis Antônio). Sampling was by Malaise traps and sweeping the vegetation. The specimens are deposited in the DCBU collection (Departamento de Ecologia e Biologia Evolutiva of the Universidade Federal de São Carlos, SP, Brazil).

The morphological terminology used in the identification and description of the new species follows Gauld et al. (2002).

\section{Results and Discussion}

\section{Seticornuta jacutinga sp. $\mathbf{n}$.}

Material examined. Holotype ${ }_{+}$, BRAZIL, Minas Gerais, Jacutinga, Morro da Forquilha, 22 ${ }^{\circ} 21^{\prime} 40.5$ ” S and $46^{\circ} 35^{\prime}$ 28.2" W, Malaise trap V, 01.IX.2009, C. R. Araujo e eq. col. Paratypes: BRAZIL, 2 q, Minas Gerais, Jacutinga, Morro da Forquilha, 22 $2^{\circ} 21^{\prime} 40.5^{\prime}$ S $\mathrm{S}$ and $46^{\circ} 35^{\prime}$ 28.2” W, Malaise trap V, 01.IX.2009, C. R. Araujo e eq. col.; 1 $\hat{\delta}$, Minas Gerais, Bom Repouso, Serra dos Garcias, $\left(22^{\circ} 29^{\prime} 25.6^{\prime \prime} \mathrm{S}\right.$ and $\left.46^{\circ} 11^{\prime} 25.8^{\prime \prime} \mathrm{W}\right)$, sweeping the vegetation, 02.IX.2009, C. R. Araujo e eq. col.

\subsection{Description}

Female: Fore wing length $4.7 \mathrm{~mm}$. Malar space about 0.6 basal mandibular width (Figure 1); maxillary palpomeres II-III weakly inflated (Figure 2); combined face and clypeus (from clypeus apex to level of antennal sockets) 1.1 times as high as wide (at the shortest distance between the eyes), with close coarse shallow punctures (Figure 1); labrum rounded apically (Figure 1); interantennal process low and obtuse (Figures 3, 4 and 11); lower face with inner margins of eyes slightly convergent ventrally (Figure 1); interocellar distance 1.8 times distance between posterior ocellus and eye (Figures 3, 4 and 11); antenna with 27 flagellomeres, more distal ones slightly elongate (Figures 10 and 11). Mesosoma with tegula weakly convex, with hind margin oblique but fairly straight (Figures 4 and 6); mesopleuron with dorsal part inflated and with fine scattered punctures well distributed anteriorly (Figure 6); subalar prominence well developed forming a sharp flange (Figure 6). Propodeum with lateromedian longitudinal carinae strong, parallel, then converging posteriorly to form a single carina joining margin of propodeal insertion (Figure 5); posterior transverse carina weak and incomplete (Figure 5). Fore wing with areolet moderately large, with 3 rs-m not fully pigmented, with petiole about 0.8 times as long as height of areolet. Metasoma with tergite I quite coarsely punctate, posteriorly about 1.3 times as broad as long (Figure 7); tergite II evenly convex, quite coarsely punctate, about 1.3 times as posteriorly broad as long (Figure 7); laterotergites II-V broad, meeting on midventral line (Figure 8); subgenital plate rather small, not concealing the slender ovipositor (Figure 9).

Head yellow with antenna dark brown (Figures 10 and 11); mesosoma yellow, mesoscutum with lateral and anteromedian dark marks (not longitudinal vittae) (Figure 11) and with propodeum brownish yellow; metasoma reddish brown (Figure 10). Legs entirely yellow (Figures 10 and 11). Wings weakly infumate; pterostigma dark brown (Figure 10).

Male: Fore wing length $4.4 \mathrm{~mm}$; maxillary palpomeres slender; interocellar distance 1.7 times distance between posterior ocellus and eye; antenna with 25 flagellomeres. Legs yellow with hind and mid tarsi dark brown.

Etymology. The name refers to Jacutinga, Minas Gerais, the location where the holotype was collected.

Diagnosis. Compared to species previously described, Seticornuta jacutinga sp. n. resembles $S$. altamirae but clearly differs from that species by the small size, narrower ocellar triangle (distance between posterior ocellus comparated with distance between posterior ocellus and eye), longer malar space; anterior part of mesopleuron more evenly punctate (not present only centrally), subalar prominence forming a sharp flange; mesosoma yellow with black marks on the mesoscutum (not longitudinal black vittae), propodeum brownish yellow, legs yellow and metasoma reddish brown.

Biological notes. Three females were collected in a dry forest fragment near coffee plantations and pasture. The single male was found in a very wet area of riparian forest. These specimens were found in areas between 1000-1500 m of altitude. The host of this species is unknown.

Acknowledgements - To INCT Hympar Sudeste and Luciana Bueno dos Reis Fernandes for the Scanning Electron Microscope images, Airton Santos Soares and Marco Aurelio Bortoni for help with samples and CAPES (Coordenação de Aperfeiçoamento de Pessoal de Nível Superior) for financial support. 


\section{References}

ARAUJO, CR. and PENTEADO-DIAS, AM., 2011. New species of Metopiinae (Hymenoptera, Ichneumonidae) from Brazil. Brazilian Journal of Biology, vol. 71, no. 1, p. 203-207. http:// dx.doi.org/10.1590/S1519-69842011000100029

DE SANTIS, L., 1980. Catalogo de los himenopteros brasileños de la serie Parasitica, incluyendo Bethyloidea. Curitiba: Editora Universidade Federal do Paraná. 395 p.

GAULD, I.; SITHOLE, R.; GOMES, JU. and GODOY, C., 2002. The Ichneumonidae of Costa Rica, 2. Memoirs of the American Entomological Institute, vol. 66, p. 768.

LA SALLE, J. and GAULD, I., 1993. Hymenoptera and Biodiversity. Wallingford: C.A .B. International. 348 p.

LOFFREDO, APS. and PENTEADO-DIAS, AM., 2008a. First record of Schizopyga Gravenhorst (Hymenoptera, Ichneumonidae, Pimplinae) from Brazil and a description of a new species. Brazilian Journal of Biology, vol. 68, p. 457-458. http://dx.doi. org/10.1590/S1519-69842008000200034

-, 2008b. First record of Ticapimpla vilmae Gauld, 1991 (Hymenoptera, Ichneumonidae, Pimplinae) from Brazil. Brazilian
Journal of Biology, vol. 68, p. 911. http://dx.doi.org/10.1590/ S1519-69842008000400032

ONODY, HC.; LOFFREDO, APS. and PENTEADO-DIAS, AM., 2009a. Notes on the Brazilian Brachycyrtus Kriechbaumer species (Hymenoptera, Ichneumonidae Brachycyrtinae). Brazilian Journal of Biology, vol. 69, p. 981-982. http://dx.doi.org/10.1590/ S1519-69842009000400030

ONODY, HC.; MELO, IF.; PENTEADO-DIAS, AM. and DIAS-FILHO, MM., 2009b. New species of Eiphosoma Cresson 1865 (Hymenoptera, Ichneumonidae, Cremastinae) from Brazil. Brazilian Journal of Biology, vol. 69, p. 1205-1206. http://dx.doi. org/10.1590/S1519-69842009000500028

TOWNES, H. and TOWNES, M., 1966. A catalogue and reclassification of Neotropic Ichneumonidae. Memoirs of the American Entomological Institute, vol. 8, p. 367

YU, DS. and HORSTMANN, K., 1997. A catalogue of Ichneumonidae (Hymenoptera). Memoirs of the American Entomological Institute, vol. 58, p. 1558

YU, D S.; ACHTERBERG, C. and HORSTMANN, K., 2005. World Ichneumonoidea 2004: Taxonomy, biology and distribution. Scientific names for information management. Taxapad CD version. 